\title{
The Effective Research of Ideological and Political Education in University under the New Media Environment
}

\author{
Qingsong $\mathrm{Li}^{1 \text {, a }}$ \\ ${ }^{1}$ Chongqing University of Education.Chongqing.400067 \\ hunter2011@foxmail.com
}

\begin{abstract}
Keywords: Ideological and Political Education, Colleges and Universities, New Media, Effectiveness
\end{abstract}

\begin{abstract}
The new media has advantages such as reflecting contemporary and radiation, infiltration and so on and it has been the new position which of the most contemporary to carry out ideological and political education in the university. But the "no barrier" and content diversification of new media weakens the function and effect of ideological and political education. Universities can enhance the effectiveness of ideological and political education in three areas: expansion of the new position of the ideological and political education, build complex and expert's ideological and political education team and improve the information regulatory mechanism of new media.
\end{abstract}

\section{Introduction}

"The current widespread use of the Internet, mobile phones, digital television and other new media has brought great changes in information dissemination, public opinion increasingly complex environment, to ideological and political education has brought new opportunities and challenges. How proactive use of modern scientific and technological means, so that students can be accepted by modern information and communication channels active and healthy thought and culture, is an important issue currently facing. We must inherit and take advantage of the traditional ideological and political education, ideological and political education to fully exploit the new media, the challenges into development the opportunity to open up new positions in the ideological and political innovation and development of education [1].

\section{The Property and Ideological and Political Education Function of the New Media}

"New media" is a relative concept and it actually changes with history and changing referent object. Any age will have new media relative. Currently, including 3G networks, blog, microblogging, mobile, virtual communities, PDA, MP4, IPTV, etc., become the contemporary significance of the "new media." New media advantage is that it has changed a multipoint mode of transmission of traditional mass media, has a good interactive, effective immediacy, highly integrated and ubiquitous network and other characteristics. Its superiority lies in education: rich in resources, convenient, open sharing, respect for individuality, interactive, virtual simulation, more humane. Technological changes lead to the production, lifestyle changes and digital new media bring human education, study, change communication, and to provide an effective dissemination of ideas and models for the contemporary education, embodied in the following three aspects [2]:

Advanced and diversity of new media provide a broad platform for the ideological and political education. The emergence of new media is under new technical support system of contemporary media forms. Advanced digital technology and the integration of diverse forms of communication, the formation of the Internet, blending and interaction between the mobile network and TV network, so that the information presented surplus geographical spread across the open characteristic culture. As the object of ideological and political education of contemporary college students are particularly concerned and are keen to accept new things. With the new media, we can play it in combination with a variety of network tools to advantage, building horizontal and vertical vector series of ideological and political education, such as the theme of the website, mobile news, 
blog, microblog, BBS, MSN, QQ and other digital campus platform to form loved by college students transfer to the ideological and political education-related content, and strive to make ideological and political education from the plane to the carrier perspective, from static to dynamic, so as to form a broad sharing platform.

Timeliness and convenience of new media greatly improve the effectiveness of ideological and political education. As the new media has the characteristics of the dissemination of information across time and space, educational content can be with "media interaction", "resource sharing" and other ways to pass from one medium to another medium terminal end, to promote the computer network and mobile phone network, all kinds of reading interconnection between, thus forming a "streaming" phenomenon, so radiation penetration greatly enhance ideological and political education, ideological and political education to achieve a new media for full coverage of college students, full inclusion, full penetration. Students can be anywhere, any time to obtain the necessary knowledge and information through mobile phones, microblog and other new media. Students also keep abreast of new media social reality, hot news about the kinds of social phenomena in different countries, ideas, familiar with the party and the country's line, principles and policies and so on.

The interactive and virtual property of new media can enhance the autonomy of college students and direction of ideological and political education. In the virtual environment, college students like to use an anonymous way to exchange ideas, transmit emotions, catharsis pressure, which makes it easier to form the virtual space openly, freely atmosphere. Colleges ideological and political education not only to keep abreast with the new media and collect the hot topics and hearts of most real college students concerned about the idea of a comprehensive, in-depth grasp of students' psychological trends and ideological trends, but also for virtualization scenario design, providing simulation problem background, reproduce interpersonal or social problems that might occur in real life, so that students become the scene in the role and autonomy to respond, experience a variety of real moral role-playing scenarios, and then teachers can target students in the virtual environment exposed thinking, learning and life problems to organize discussions and feedback to the reality in a targeted manner to carry out ideological and political education, received the traditional unity, planar mode of education incomparable effect [3].

\section{The Negative Impact of New Media on the Ideological and Political Education in University}

The property of "no barrier" of new media increases the difficulty of ideological and political education. BLOG, E-mail, MSN and other new media without borders, information dissemination super regional, cross-cultural characteristics open wide its contents but disorderly. Since the new media is not just communication tools, also plays shaping ideas and construct concepts function, so that different ideologies and cultures all political forces strive to use its propaganda, to compete audience. Post new media interventional campus information, dissemination and use of more freedom, a few Western countries, by virtue of the high-tech network monopoly, the output of its ideology, values and certain decadent cultural ideas and lifestyles. Students not yet formed stable values, still form a rational judgment, if the long-term effects of bad information that is easily lead to lost ideals and beliefs, values confusion, legal and moral consciousness weakened, ideological and political education so as to increase the difficulty.

The virtual property of new media is apt to cause some personality and cognitive disorder of college students. New Media has a strong virtual sex and anonymity, which gives the behavior provides a great degree of freedom, people's subjectivity and creativity into full play. But some college students immature, to identify weak, in a virtual environment is easy to indulge in a virtual space free to play initiative, personality and virtual reality personality change frequently, easy to induce personality disorders and weakened sense of responsibility; some college students escapism, immersed in Unreal personal achievement among interpersonal alienation, likely to cause psychological disorders and cognitive biases, and sometimes even lead to criminal acts of moral anomie. Such as the use of new media publishing false news, spread rumors, manufacture virus 
software and even steal money and lie to others, and so on through the network.

New media content diversification weakened the function and effect of ideological and political education. New media information dissemination in a dispersed state, with uncertainty and discrete, multi-dimensional propagation mode increases the difficulty of government control of information sources. Under the new media environment, complex and diverse excessive information affecting college students to identify and select the right to information. Especially over the pursuit of commercial interests, some of the new media is filled with fast-food culture, vulgar culture, and some touched the bottom line of social morality and public values, to a certain extent, interfering with people's ideas, feelings and attitudes, interfering with the value of college students' judge, lifestyle and ideals. Contemporary, mainstream values and different ideologies presented from time to time in the new media, the different value perspectives and diverse new media content so that part of university students within the socialist core value system into their own value in the process of pursuing an adverse interference and increasing the difficulty of the ideological and political education, weaken the function and effect of ideological and political education [4].

\section{The Measures to Enhance the Effectiveness of Ideological and Political Education in the New Media Environment}

Expand the new position of ideological and political education to enhance guidance and penetration under the new media environment. In the new media environment, ideological and political education in colleges and universities cannot be limited classrooms and classroom time should be extended to extra-curricular, and build three-dimensional position of the ideological and political education to the new campus life anchored the new media and the integration of traditional strengths. First, the expansion of the ideological and political education of new media channels for ideological and political education in "into teaching materials, classroom" based on "into the media." Support for more news, information, culture and party organizations into the network, the use of new media technology, integration of information resources of various departments, to create "close to reality, teachers and students, to life," the fusion of ideology, knowledge, interest, service in one of the ideological and political education websites, to build the website into the information base, knowledge base, think tanks, pay attention to the guiding role of public opinion agenda-setting, which is actually "infiltrating" hidden ideological and political education in the new media environment use. Second, the use of new media to promote ideological and political education effective interaction with the students. Ideological and political education workers use E-mail, QQ, MSN, BBS, blog, microblog and other new media platforms, in a timely manner for the hot issues of concern college students, to strengthen the interaction with students form a positive ideological and political education of public opinion, effectively socialist core values into the ideological consciousness and behavior. Third, the use of new media to create a healthy, lively campus culture. Ideological and political education workers can give full play to the advantages of the new media, grasp the entry point, well-designed, through special news, academic lectures, hot discussions, debates speeches, example publicity, etc., efforts to purify the socialist core value system of campus culture propagation environment, better to create a healthy, lively campus culture, to help students form a correct outlook on life and values.

Enhance media literacy of teachers and students to create complex and expert' ${ }^{`}$ ideological and political education team. Media literacy refers to public access, interpretation, use of media quality and training, including three aspects: contact with the media, access to information; interpret media critically accepting media messages; use the media work and life, through the medium of sound and maintain their own interests. Political Educators media literacy is not just to "convince" to improve the ability of information, "Delivery", more important is the message, "analysis", "identification", "filter", "evaluate", "guide" to enhance the ability of and perfect. With the development of colleges and universities to really change with the times of ideological and political education team put forward new demands, adapt to the new media era to build a high-quality workforce development needs [5]. 
Improve the information regulatory mechanism of new media, enhance the effectiveness of the ideological and political education. Colleges and universities while socialist core value system to guide new media and public positions, and actively integrate the advantages of the new media resources, we must optimize the new media information environment, establish regulatory mechanisms campus information of new media, new media and technical conditions for the dissemination of information channels, approaches a more strict supervision and management, the formation of organic management to run the chain, which is to do in the new media environment of ideological and political education work organizational guarantee. This is a complicated systematic project, we must fully mobilize all favorable factors the government, schools, society and families. Government departments to strengthen the information network, mobile phones and other new media monitoring and management, speeding up the construction of the new media regulatory information production and dissemination, review and filtering information according to the law, to strengthen the defense capabilities of the socialist ideology, purify the network from the source.

\section{Conclusion}

In the new media environment, the university should establish a sound campus media information regulatory mechanism. Through the construction of virtual organizations, the establishment of a network administrator and other ways to increase supervision of information dissemination. And we also need the timely establishment of the campus network spokesman mechanism and emergency preparedness and rapid response mechanism for group events. In the new media environment, promote the theme of Chinese special socialism, form a healthy public opinion and enhance the effectiveness of the ideological and political education.

\section{References}

[1] J.X. Xie, The changes of ideological and political education work ethic since the reform and opening up, J. Ideological and Political Education Research, 25(2009) 3.

[2] G. Li, The practical significance of the "people-oriented" university moral education, J. China Youth College for Political Sciences, 4(2003) 96.

[3] Y. Shan, The modern ideological and political education should focus on training human subjectivity, J. Theory and Reform, 4(2003) 114.

[4] J.X. Li, The function of new media technology on Ideological and political education, J. Moral Research .9(2009) 19-22.

[5] Y.X. Zhang, Impact and countermeasures of new media on political socialization of college students, j. Chinese Youth Studies. 4(2007) 129-132. 